\title{
Geochemistry and mineralogy of recent sediments of Guanabara Bay (NE sector) and its major rivers - Rio de Janeiro State - Brazil
}

\author{
MARCIA DE MELO FARIA ${ }^{1}$ and BRAZ A. SANCHEZ ${ }^{2}$ \\ ${ }^{1}$ DERNA/DGC/IBGE, 20031-170 Rio de Janeiro, RJ, Brazil \\ ${ }^{2}$ LAGEMAR, Instituto de Geociências, Universidade Federal Fluminense, 24210-340 Niterói, RJ, Brazil \\ Manuscript received on September 15, 1999; accepted for publication on August 4, 2000; \\ presented by Diogenes de Almeida CAmpos
}

\begin{abstract}
Geochemical and clay mineralogical studies of bottom sediments collected along the Macacu and Caceribu rivers and Guanabara Bay were carried out in order to investigate the relationship between major source areas and recent sediments of the bay.

Clay mineralogy includes different groups with selective distribution conditioned by geomorphic features and depositional settings. Micaceous clay minerals are abundant near parent rock in the upper course, whereas kaolinite derived from varied sources is gradually concentrated towards the estuary. In the Guanabara Bay, kaolinite accumulates near river mouths, while micaceous clay minerals are converted into mixed layers in the estuary.

Analyses of heavy metal contents reveal higher levels of $\mathrm{Zn}$ and $\mathrm{Cu}$ in sediments of the bay than in river sediments. Profiles along rivers indicate a downstream decrease of heavy metals, whereas in the bay geochemical trends display greater variations. In general river mouth sediments present the lowest concentrations. At the north and east of Paquetá Island anomalous areas with the highest heavy metal contents occur.

$\mathrm{Cu}$ tends to concentrate in $<2 \mu \mathrm{m}$ grain-size fraction and indicates an association with micaceous clay minerals in the upper river course. However, $\mathrm{Cu}$ retention seems to be further controlled by other components of bottom sediments due to changes in physical and chemical conditions of the estuarine environment. $\mathrm{Zn}$ shows unstable behavior along the rivers and concentrates in the bay. $\mathrm{Pb}$ displays small variations from river to bay sediments, and accumulates mainly in the $<63 \mu \mathrm{m}$ grain-size fraction without any association with clay mineral.

Geoaccumulation indexes of $\mathrm{Cu}, \mathrm{Pb}$ and $\mathrm{Zn}$ classify the study area as unpolluted in both studied rivers and in the NE sector of the bay, though the enrichment factors are higher in the bay. The study does not indicate those rivers as major sources of heavy metal pollution to the bay.
\end{abstract}

Key words: heavy metal, clay mineral, sediment, Guanabara Bay.

\section{INTRODUCTION}

Estuaries have been subject of considerable scientific interest over the last decades because of their environmental significance as material traps, and as

Correspondence to: Marcia de Melo Faria

E-mail: mamf@ibge.gov.br such they require careful and constant monitoring and management. Estuaries can be thought as filters of the river-transported chemical components, which can often emerge from the mixing zone under a considerably modified form (Schink 1980 apud Chester 1990). The measurement of pollutants 
in estuarine sediments plays an important role because of longer residence time in sediments than in the water and in suspended matter associated with discharge fluctuations. Like records of earlier pollution sediments have been increasingly recognized as carriers and possible sources of contaminants in the aquatic system (Förstner \& Wittman 1981, Malle 1990).

The close association between some heavy metals and clay minerals is demonstrated by several pathway studies, but analyses on estuarine sediments are very few when compared to marine sediments (Malle 1990). Clay minerals are characterized by large surface areas per mass unit, which accounts for their capacity of enrichment in heavy metals. Thus the clay-size fraction can be a reliable indicator of environmental pollution (Förstner \& Wittman 1981, Jenne 1977 apud Rybicka et al. 1995).

Guanabara Bay is an important Brazilian estuary located in the southeast coast of Brazil (Fig. 1), which has been receiving high amounts of urban effluents during last decades. Human activities (intensive urbanization and industrialization processes) promote the inflow and accumulation of polluted sediments mainly derived from the cities as Rio de Janeiro, Duque de Caxias, Nova Iguaçu, Niterói and São Gonçalo. The northeast sector of the bay was considered a "protected" area related with rural catchment areas, but Faria et al. (1995) reported a recent increase in heavy metal contents in the bottom sediments of the bay.

This study focuses on several geochemical parameters and clay mineral distribution patterns in recent sediments of inner Guanabara Bay and its major rivers.

\section{Study Site}

The northeast sector of the bay is very shallow ( $3 \mathrm{~m}$ in average). The tidal currents have the lowest velocities during the winter, $31 \mathrm{~cm} \mathrm{~s}^{-1}$ in the upper layer ( $3 \mathrm{~m}$ below sea surface) during the flood tide and $16 \mathrm{~cm} \mathrm{~s}^{-1}$ in the ebb tide. In the summer, ve- locities range from $48 \mathrm{~cm} \mathrm{~s}^{-1}$ in the flood tide to $19 \mathrm{~cm} \mathrm{~s}^{-1}$ during the ebb tide (JICA 1994). The lowest salinities of the bay are located in this inner sector. Large amounts of sediments and fresh water are provided by the northeastern rivers, which are strongly seasonal, reaching highest river discharges during the rainy summer (monthly averages of the Macacu River: $116 \mathrm{~m}^{3} \mathrm{~s}^{-1}$ and Caceribu River: $128 \mathrm{~m}^{3} \mathrm{~s}^{-1}$, Amador 1992). The area lies just within the tropics in southeastern Brazil, but because of its coastal location a humid sub-tropical climate with $2,500 \mathrm{~mm}$ (high mountains) and $1,500 \mathrm{~mm}$ (low land) of rainfall predominates between December and April. Mean annual temperature is between 20$25^{\circ} \mathrm{C}$, but depends upon altitude and distance from the sea (Nimer 1989).

The study area can be subdivided into two main sectors, north and south, which include a wide variety of rock types of several ages (pre-Cambrian, Tertiary and Quaternary). The Macacu river is the main channel of the northern catchment area, draining the high mountains of Serra dos Órgãos, whereas the Caceribu river is located in the southern catchment, draining the low mountains of Serra de Maricá. Considering forty-five streams flowing into the bay, the Macacu and Caceribu rivers have the largest catchment areas representing a total area of 2,700 $\mathrm{km}^{2}$. In contrast to other rivers that flow through the urban regions, both drainage networks are mostly influenced by rural activities, such as plantations (coconut, banana, orange, mandioca) and pasture along their wide floodplains. In addition, the study area also comprises a typical estuarine ecosystem covered with a mangrove forest which extends $10 \mathrm{~km}$ landward.

\section{METHODS}

Clay mineral composition and heavy metals concentrations of $\mathrm{Cu}, \mathrm{Pb}$ and $\mathrm{Zn}$ were determined in bottom sediment samples taken along the rivers and within the estuary.

Geochemical analyses were carried out for eigth surface sediment samples from river stations 


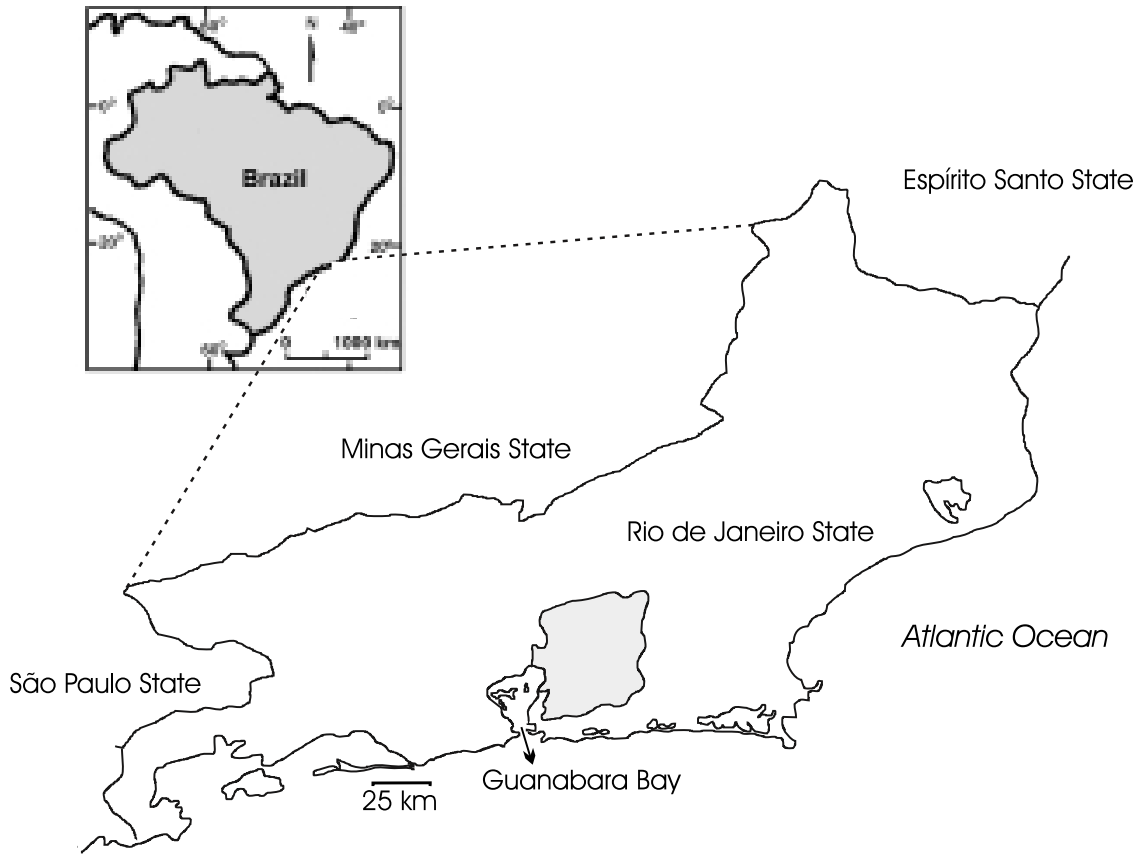

Fig. 1 - Location map of Guanabara Bay.

and eleven samples from the bay. Each sample was analyzed for two grain-size fractions: $<63 \mathrm{~mm}$ and $<2 \mathrm{~mm}$. The samples were digested with $\mathrm{H}_{2} \mathrm{~F}_{2}$ $\left(1 \mathrm{HCl}-3 \mathrm{HNO}_{3}\right)$ in a teflon bomb at $110^{\circ} \mathrm{C}$ for 1 hour. After this procedure, $\mathrm{Cu}, \mathrm{Pb}$ and $\mathrm{Zn}$ were analyzed in atomic absortion spectrophotometer. For quality control, USGS standards were prepared and analyzed together with the samples using the same procedures and reagents.

For mineralogical analyses, ten sediment samples were separated for identification of clay minerals. These were determined from the $<2 \mu \mathrm{m}$ sizefraction previously freed of most interfering organic substances, salt, carbonate and iron (Jackson 1975). The samples were dispersed with ultrasonic waves and oriented on a glass slide. These clay slides were then successively run through an X-ray diffractometer Jeol - JDX 8030, under air-dried, ethylene glycol solvated and heated at $500^{\circ} \mathrm{C}$ in the $2 \theta$ range between 2-32 ( $\mathrm{Cu} \mathrm{k} \alpha$ radiation). Identification of clay minerals and determination of their abundance were based on DRX laboratory procedures according to Alves (1987). $\mathrm{KCl}$ saturation was performed to detect the presence of vermiculites in the bay sediments (only for station B1).

\section{RESULTS AND DISCUSSION}

\section{MACACU River}

The bottom sediments upstream of M3 station are coarser, with high contents of sand, mainly derived from high mountains of Serra dos Órgãos. In upper Macacu the very low content of clay fraction mostly consists of micaceous clay minerals like illite, vermiculite, illite/vermiculite mixed layers (Fig. 2), related to high gradients of mountains (Fig. 3). These minerals represent the fine grained mica group, that concentrates near the source areas and decrease downstream to the plain regions. Along the floodplain, kaolinite concentrations increase toward the estuary, followed by mixed-layers and traces of gibbsite which also compose the clay mineral assemblages. The hot and humid climate favour chem- 


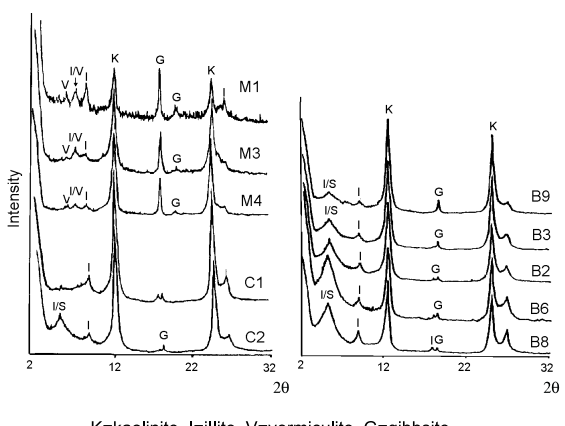

$\mathrm{K}=$ kaolinite, I=illite, $\mathrm{V}=$ vermiculite, $\mathrm{G}=$ gibbsite,

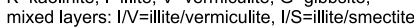

Fig. 2 - Ethylene glicol X-ray patterns in bottom sediments of Macacu and Caceribu rivers and Guanabara Bay. $\mathrm{K}=$ kaolinite, $\mathrm{I}=$ illite, $\mathrm{V}=$ vermiculite, $\mathrm{G}=$ gibbsite; mixed layers: $\mathrm{I} / \mathrm{V}=$ illite/vermiculite, $\mathrm{I} / \mathrm{S}=$ illite/smectite.

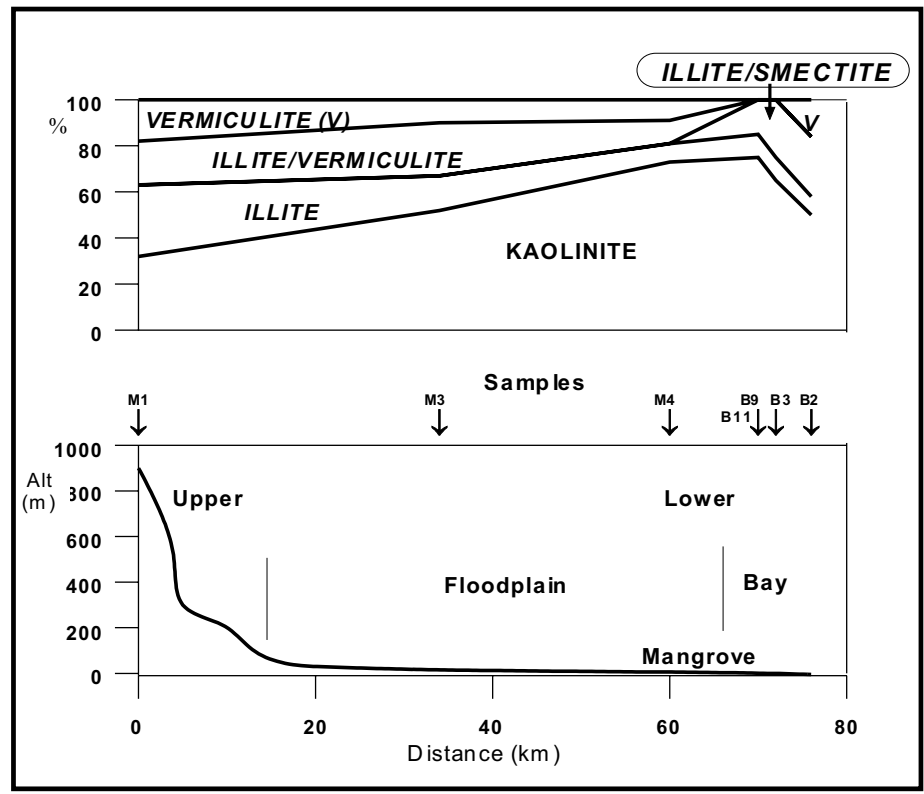

Fig. 3 - The relationship between clay mineral proportions and topographic profile of Macacu river.

ical weathering processes that together with high leaching originate this typical mineral assemblage. However, strong mechanical abrasion in the upper course makes physical weathering more efficient in formation of micaceous clay minerals (Faria 1997).
Kaolinite concentration in the lower Macacu probably records the total kaolinite derived from different weathering processes operating upstream, such as the conversion of micaceous clay minerals due to progressive leaching and also feldspar hydrolysis in 
soils and rocks.

Downstream geochemical profiles (Fig. 4) show a decreasing trend of heavy metals, except $\mathrm{Zn}$ in $63 \mu \mathrm{m}$ grain-size fraction in Macacu river sediments. The results also show a tendency of $\mathrm{Cu}$ and $\mathrm{Zn}$ concentration in the $2 \mu \mathrm{m}$ grain-size fraction. Downstream of station M2 the river receives urban effluents from smaller cities like Cachoeiras de Macacu, Guapi-Mirim and Magé, and also crosses a fishing club at station M4. Except for the very high concentration of $\mathrm{Zn}$ in station M4, apparently related to motorboat-generated pollution, heavy metal concentrations tend to decrease downstream even under influence of these cities. Chester and Aston (1976) recognize that the overall chemical composition of river-transported sediments is controlled by a number of factors. These include the geological nature of the catchment area; the drainage conditions; the intensity of local weathering processes and anthropogenic contamination, which can be significant in certain regions. The Macacu River does not exhibit an increasing trend despite urban input of heavy metals because its drainage network is very efficient and the leaching is most intense in its catchment, thus dispersing the trace elements.

In the clay fraction, $\mathrm{Cu}$ and $\mathrm{Zn}$ concentrations decrease downstream more rapidly until station M3, apparently associated with micaceous clay minerals. Furthermore, organic matter and kaolinite contents are very abundant in the estuarine sediment. Pandarinath and Narayana (1992) reported desorption mechanism in estuarine environment. This may be a possible reason for poor correlation between heavy metals and clay minerals in the Macacu estuary, since kaolinite does not correlate with the studied metals. On the other hand, humic acids can exert a high influence in the speciation of some metals within river waters, especially under low $\mathrm{pH}$ values. Mantoura et al. (1978 apud Chester 1990) predicted that more than $90 \%$ of the $\mathrm{Cu}$ and $\mathrm{Hg}$ in river waters are complexed by humic material. $\mathrm{Hu}$ mic complexed material tends to decrease with increasing salinity, but this decrease, which is rapid for $\mathrm{Mg}, \mathrm{Ca}, \mathrm{Zn}, \mathrm{Cd}, \mathrm{Mn}$ and $\mathrm{Co}$, is slow for $\mathrm{Cu}$ and $\mathrm{Hg}$ (Chester 1990). Both metals, mainly Cu, could be partly retained by organic matter, very abundant in the mangrove forest zone, which may explain the lowest heavy metal concentrations detected in this region.

\section{CACeribu River}

The highest sample station $\mathrm{C} 1$ is located in the middle course of the river and its sediment is mostly composed of fine sand fraction (Faria 1997). Downstream, silt makes up the dominant fraction and the organic matter content increases in the sediment. Clay mineralogy is very similar to that of Macacu River (Fig. 2), only differing by the absence of vermiculite. Kaolinite is concentrated along the river toward Guanabara Bay, and illite/smectite mixed layers also appear in estuarine sediments.

The geochemical profiles (Fig. 4) in Caceribu river also show a decreasing trend toward estuary in both analyzed grain-size fractions, but heavy metals do not display tendencies to concentrate in the clay fraction. Cu levels are lower than in the Macacu river and the lowest concentration is located in the river mouth (station B11). In comparison to Macacu river, Caceribu includes in its catchment a greater number of towns like Rio Bonito, Tanguá, Porto das Caixas and Itaboraí, despite that heavy metal contents were lower than those analyzed in Macacu River sediments. The southern catchment area presents different aspects from the geomorphological and geological viewpoints. The relief does not consist of high mountains, but is dominated by the lower mountains of the Serra de Maricá, the rock composition of which is notably poor in $\mathrm{Cu}$ (Braz Sanchez unpubl. data). Furthermore, traces of gibbsite also occur in the clay-size fraction of river sediments. The lower gibbsite content of Caceribu samples as compared to Macacu may reflect the more intense leaching in the Macacu catchment. This can be attributed to the geomorphological properties of Serra dos Órgãos and its higher precipitation rates. In addition, the north rivers have higher contents of mafic minerals in their 


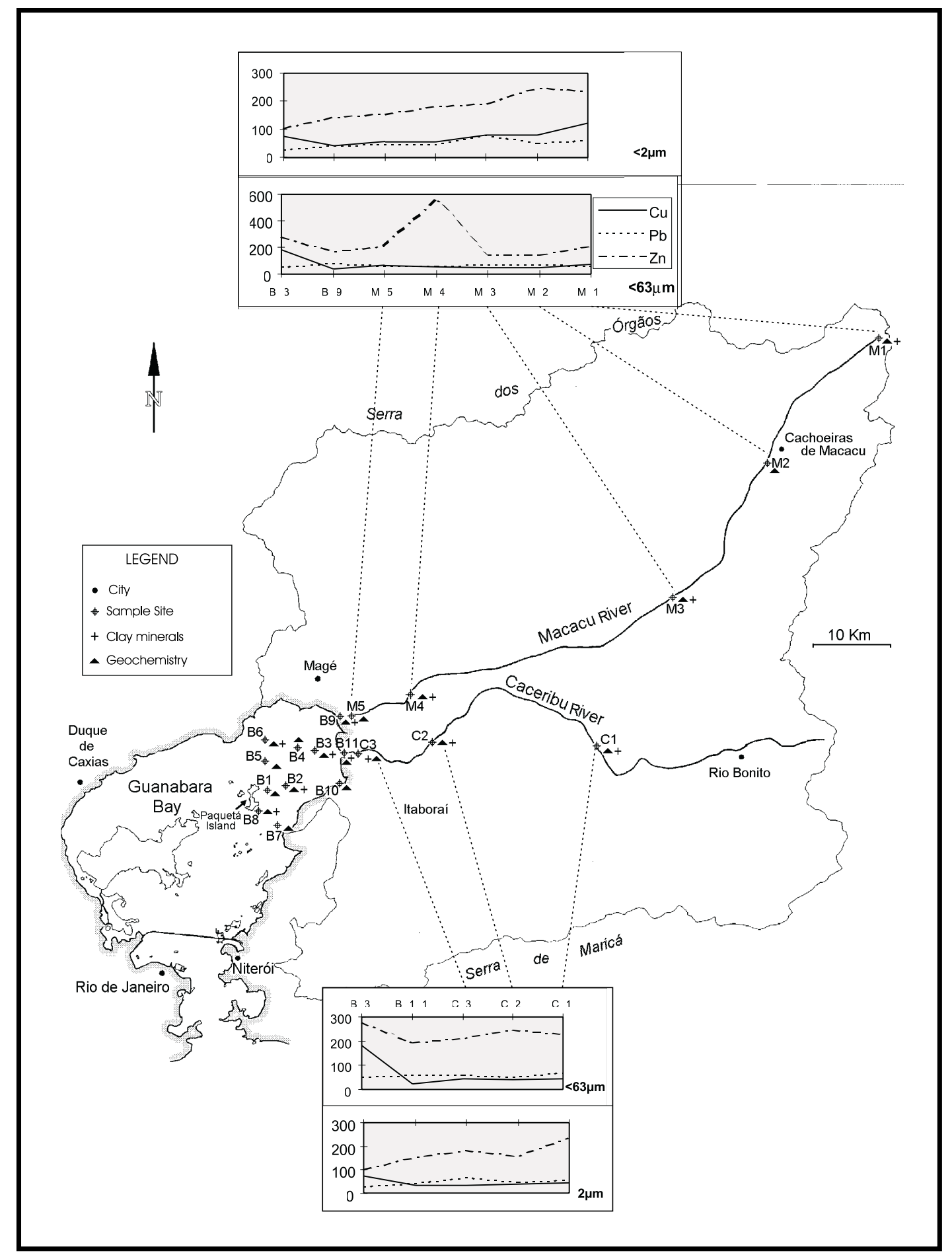

Fig. 4 - Location map of major rivers of Guanabara Bay with samples sites (M1-M5 for Macacu River, C1-C3 for Caceribu River and B1-B11 for bay stations) and heavy metals profiles ( $\mathrm{Cu}, \mathrm{Pb}$ and $\mathrm{Zn}$ in $<63 \mu \mathrm{m}$ and $2 \mu \mathrm{m}$ grain-size fractions). 
bedload differing considerably from Caceribu river sediments (Faria 1997). Lithological units in the southern catchment comprise mostly rocks with acid composition, providing a natural background which superimposes the anthropogenic input of heavy metals to the sediment. The main difference between the rivers is observed in $\mathrm{Cu}$ profiles, with lower values in Caceribu river, whereas $\mathrm{Zn}$ concentrations are very similar in $2 \mu m$ fraction. $\mathrm{Pb}$ profiles have the same pattern, and concentrations are also very similar in both rivers.

\section{Guanabara Bay}

The bottom sediments of the inner sector of Guanabara Bay consist of mud, up to $80 \%$ of $63 \mu \mathrm{m}$ fraction (Haekel et al. 1985) with a high content of organic matter. The sediment is mostly terrigenous, and dominant clay-size fraction includes mainly kaolinite in addition to illite (mica), vermiculite, illite/vermiculite and illite/smectite mixed layers (Figs. 2 and 5). In the Bay, kaolinite tends to flocculate and concentrate near the river mouths, whereas the content in illite/smectite mixed layers increases seaward. Small amounts of illite are recorded in the sediments, and illite distribution in the bay is homogeneous.

In average, Guanabara Bay sediments have higher levels of $\mathrm{Cu}$ and $\mathrm{Zn}$ than the continental sediments (Table I). Therefore, the same comparison for $\mathrm{Pb}$ revealed that there is a minor variation in the $\mathrm{Pb}$ content among these depositional environments. In general, heavy metal distribution patterns indicate river mouths as the regions with the lowest concentrations in both analyzed fractions (Figs. 6, 7 and 8). They also indicate anomalous sectors of high concentrations on the north and east sides of the Paquetá Island, probably related to anthropogenic input from the island and other polluted areas around the bay. According to JICA (1994), the major pollution sources are the high effluent loads of the industrial complex from northwestern basins of the bay. Furthermore, the urban pollution derived from densely industrialized and residential ar- eas, roads, railroads, airports, harbours. Artificial embankments in Rio de Janeiro and Niterói cities affect mainly the southern area of the bay, although it may reach the inner part of the bay due to tidal current action. The analysis of the heavy metal trends eliminate these major rivers as pollution sources to the bay as their heavy metal inputs are seemingly unrelated to the origin of these anomalies.

\section{TABLE I}

Heavy metals concentrations in average shale, Macacu River, Caceribu River and Guanabara Bay sediments.

\begin{tabular}{l|ccc}
\hline & $\mathrm{Cu}$ & $\mathrm{Pb}$ & $\mathrm{Zn}$ \\
\hline $\begin{array}{l}\text { Average shale } \\
\text { Macacu river } \\
\quad \text { sediments }(<63 \mathrm{~mm})\end{array}$ & 58 & 20 & 95 \\
$\begin{array}{c}\text { Caceribu river } \\
\text { sediments }(<63 \mathrm{~mm})\end{array}$ & 43 & 62 & 228 \\
$\begin{array}{c}\text { Guanabara Bay } \\
\text { sediments }(<63 \mathrm{~mm})\end{array}$ & 119 & 69 & 290 \\
$\begin{array}{c}\text { Macacu river } \\
\text { sediments }(<2 \mathrm{~mm})\end{array}$ & 79 & 57 & 204 \\
$\begin{array}{c}\text { Caceribu river } \\
\text { sediments }(<2 \mathrm{~mm})\end{array}$ & 40 & 58 & 194 \\
$\begin{array}{c}\text { Guanabara Bay } \\
\text { sediments }(<2 \mathrm{~mm})\end{array}$ & 78 & 40 & 199 \\
\hline
\end{tabular}

*Turekian and Wedepohl (1961) apud Förstner and Wittman (1981). The concentrations are in ppm.

Geochemical and mineralogical data indicate that the lowest concentrations of heavy metals are located in kaolinite-rich sediments. However, the highest heavy metal concentrations do not correlate with any clay mineral group, which may be attributed to changes in physical and chemical estuarine conditions. In addition, the role of organic matter in the formation and transformation of clay minerals, as well as in heavy metal adsorption have not been well investigated in this sector of the bay.

The finest grain-size fraction of river sediments point out to a continuous enrichment in heavy met- 


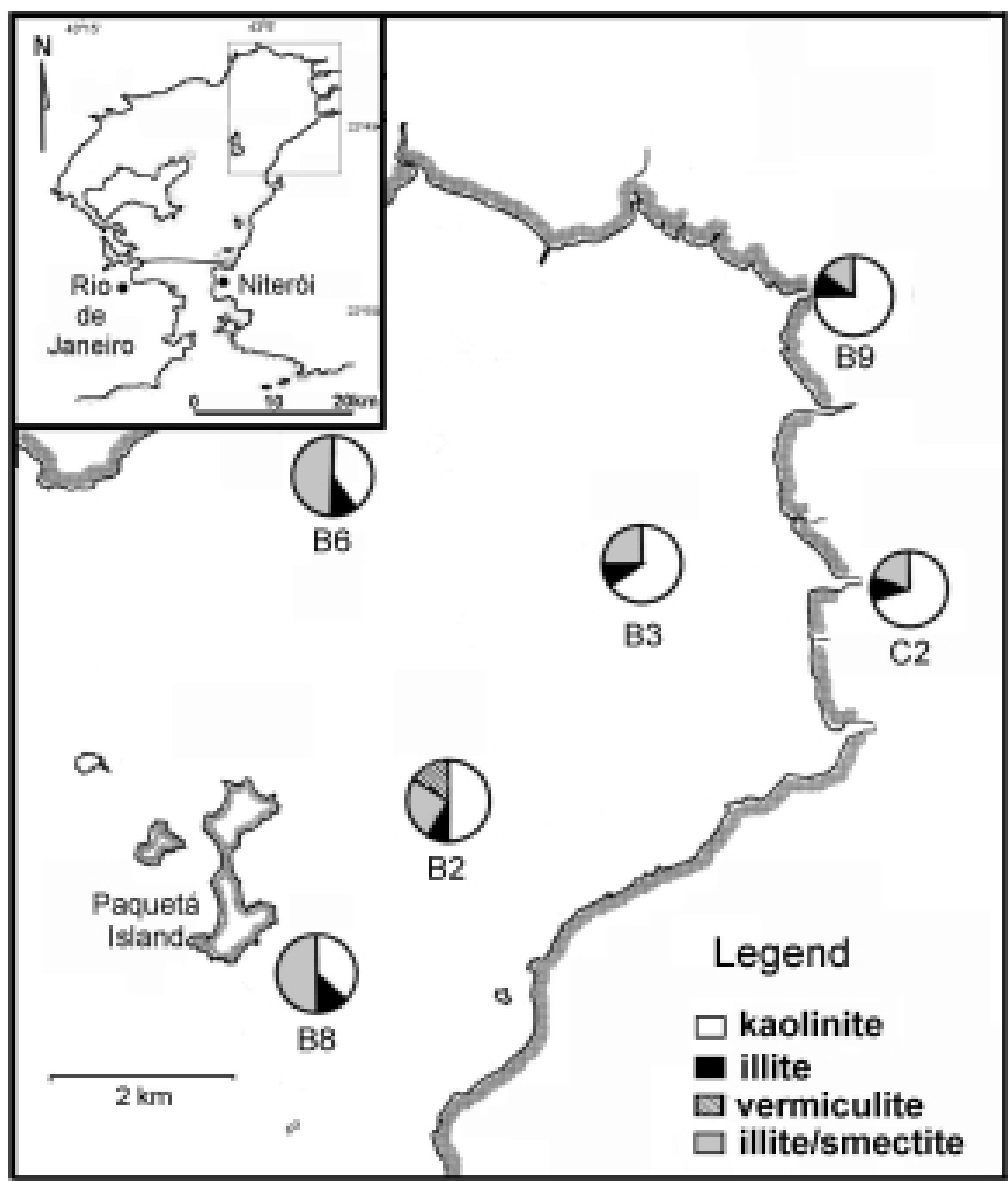

Fig. 5 - Clay mineral distribution in bottom sediments of northeastern sector of the bay (relative percent of $2 \mu \mathrm{m}$ grain-size fraction).

als due to the active surface of Fe-oxides and clay minerals (Förstner \& Wittman 1981). Metal sorption reactions of metals in different competing clay minerals studied by Rybicka et al. (1995) show the highest $\mathrm{Pb}$ enrichment for smectite and illite. Several environmental studies use clay mineral associations in sediments to trace the sediment transport in the estuarine environment (Irion \& Zöllmer 1990, Pandarinath \& Narayana 1992, Wijayananda \& Cronan 1994). This association could not be observed for $\mathrm{Pb}$ in the studied area because $\mathrm{Pb}$ concentrations in $<63 \mu \mathrm{m}$ fraction are higher than in $<2 \mu \mathrm{m}$ fraction. This is probably related to the presence of feldspar, which like quartz is a very common min- eral in bottom sediments. The association of both $\mathrm{Cu}$ and $\mathrm{Zn}$ with clay minerals is unclear in the bay, possibly because other components or combinations of them that may have played a more significant role in mobilization processes of these heavy metals.

\section{Sediment Pollution}

The quantification of pollution has been calculated by using an enrichment factor with respect to average shale (Turekian \& Wedepohl 1961 apud Förstner \& Wittman 1981). Table II shows the metal enrichment factors for Macacu and Caceribu river sediments and the Guanabara Bay sediments. The table also indicates higher factors for $\mathrm{Pb}$ in relation to $\mathrm{Cu}$ 


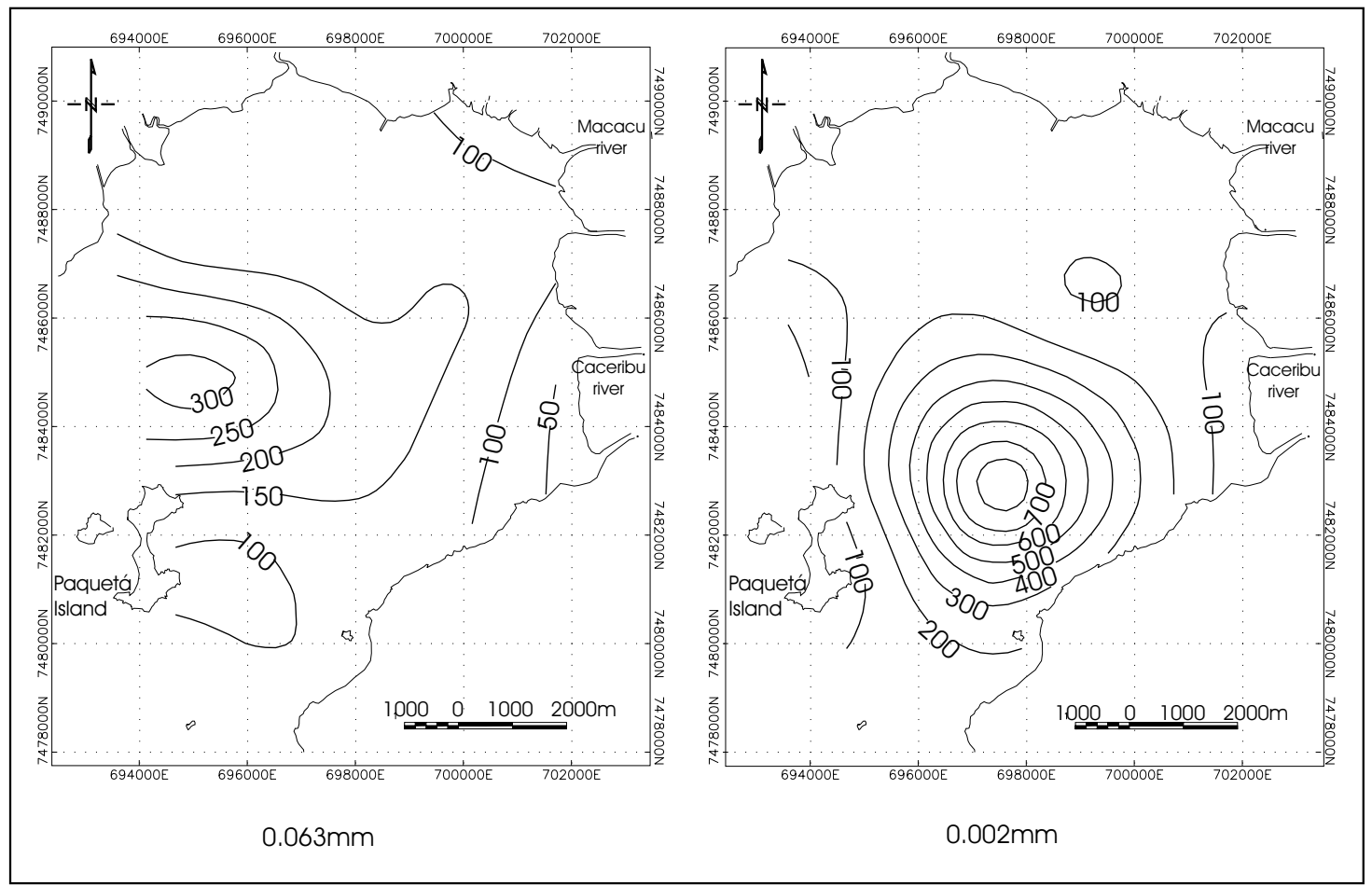

Fig. 6 - Cu distribution in bottom sediments of northeastern Guanabara Bay (contour lines are in ppm).

and $\mathrm{Zn}$ factors. The average was also calculated, and Figure 9 shows the input relation between the rivers and the bay. $\mathrm{Cu}$ average enrichment factor in the rivers remains within the natural background, characterized by lower average (1.0), whereas $\mathrm{Zn}$ and $\mathrm{Pb}$ averages reflect anthropogenic inputs in both studied environments (2.1 for $\mathrm{Zn}$ and 2.7 for $\mathrm{Pb}$ in the rivers, and 2.4 for $\mathrm{Zn}$ and 2.7 for $\mathrm{Pb}$ in the bay). Baptista Neto (1996) studied the sediments of the south of the bay, under high urban influence, and detected a wider range of enrichment factors for these metals (4.5-27 for $\mathrm{Cu}, 2-8$ for $\mathrm{Pb}$ and 3-10 for $\mathrm{Zn}$ ). The geoaccumulation index proposed by Müller (1979) for the pollution quantification was also calculated for sample stations, but in all of them the index remains in class 0 , or unpolluted for $\mathrm{Cu}, \mathrm{Pb}$ and $\mathrm{Zn}$.

\section{CONCLUSIONS}

The rivers provide high contents of kaolinite to the bay, as well as minor proportions of illite (mica), ver- miculite, illite/vermiculite and illite/smectite mixed layers. Besides climatic conditions, topography is an important factor that also controls the conversion and distribution of clay minerals along the rivers. In addition, gibbsite is relatively more abundant in Macacu sediments than Caceribu, possibly due to more efficient leaching attributed to the geomorphic features of Serra dos Órgãos. In the bay, a selective distribution of clay minerals occurs in function of fluvial discharges and hydrodynamic conditions of the bay, so that kaolinite tends to concentrate near the river mouths and illite/smectite mixed-layers concentrates seaward.

In general, heavy metals do not correlate with any specific clay mineral. However $\mathrm{Cu}$ tends to concentrate in $<2 \mu \mathrm{m}$ grain-size fraction of river sediments and is apparently related to micaceous clay minerals in the upper course of rivers. Other factors, including components of the sediment with higher capacity of adsorption and complex changes 


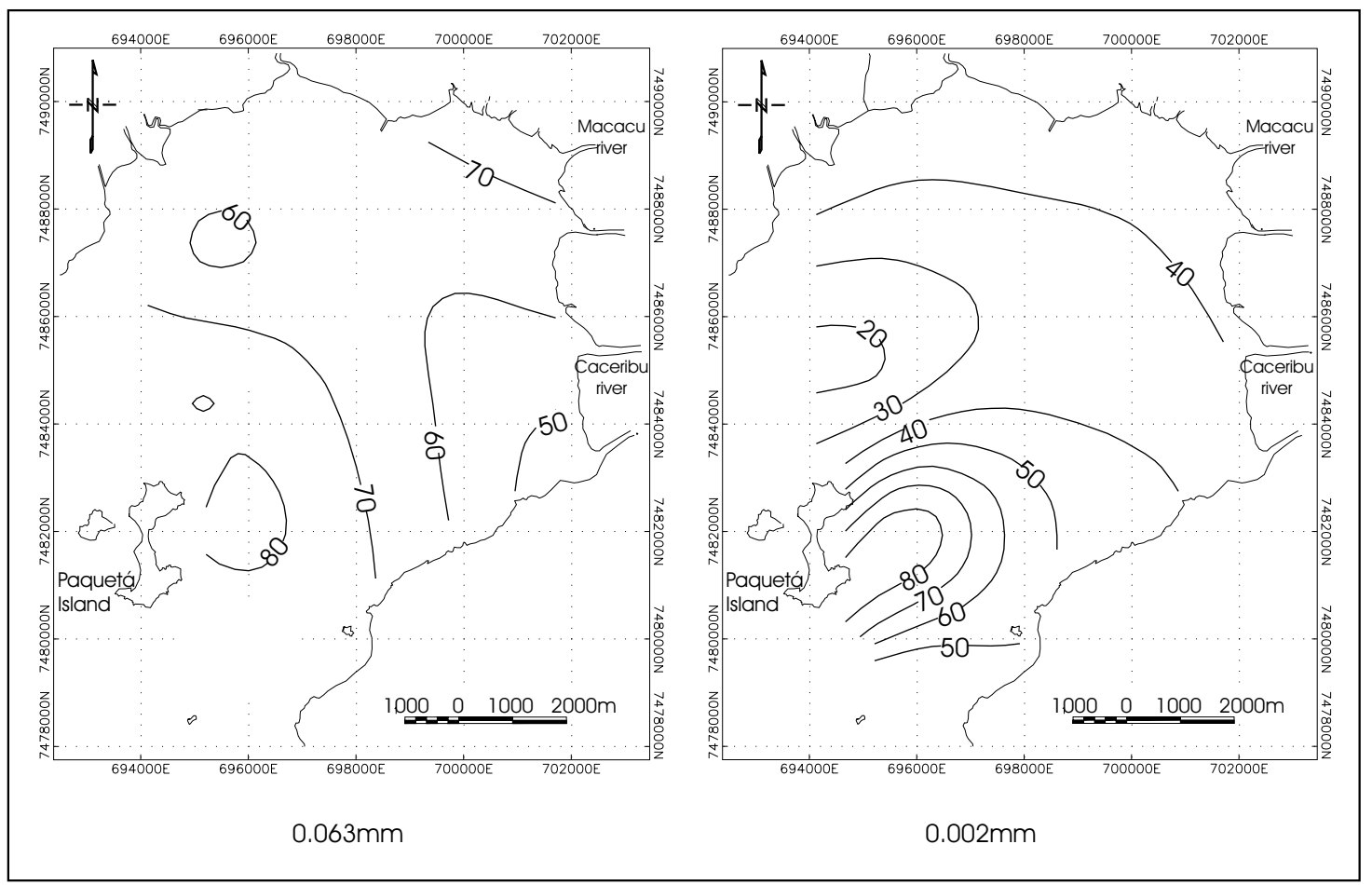

Fig. 7 - Pb distribution in bottom sediments of northeastern Guanabara Bay (contour lines are in ppm).

in physico-chemical conditions of the estuary, should be checked in future studies.

Heavy metal profiles exhibit a decreasing downstream trend along the rivers with lowest concentrations located in the river mouths. Concentration maps indicate highest concentrations to the north and east of Paquetá Island in Guanabara Bay. Heavy metal levels of river sediments reflect the geochemical properties of the source areas. The mangrove forest with its organic mud substrate seems to control the heavy metal supply to this inner sector of the bay, which still remains relatively unpolluted.

\section{ACKNOWLEDGEMENTS}

The authors are grateful to Dr. John McAlister and Dr. Bernard Smith of Queen's University of Belfast for the lab facilities during geochemical analyses. The authors also thank to Dr. Sylvia dos Anjos and Dr. Daisy B. Alves of PETROBRÁS for DRX analysis and assistance during the clay mineral identifica- tions, to Dr. Rene Rodrigues for valuable comments to improve the content of this work and to Dr. José Henrique G. Melo for the English review. Thanks are also extended to CAPES and CNPq for financial support.

\section{RESUMO}

A correlação dos sedimentos recentes da Baía de Guanabara com as suas principais áreas-fontes foi realizada a partir de análises geoquímicas e de argilominerais em amostras de fundo coletadas ao longo dos rios Macacu e Caceribu e na baía.

Os argilominerais indicam uma distribuição seletiva intimamente associada às características do relevo e aos ambientes deposicionais. Os argilominerais micáceos são predominantes na região do alto curso próximos à áreafonte primária, enquanto que a caulinita, proveniente da decomposição de diversos minerais, se concentra gradativamente em direção ao estuário. Na Baía de Guanabara observa-se um acúmulo de caulinita na região de foz dos rios, ao passo que os argilominerais micáceos são con- 


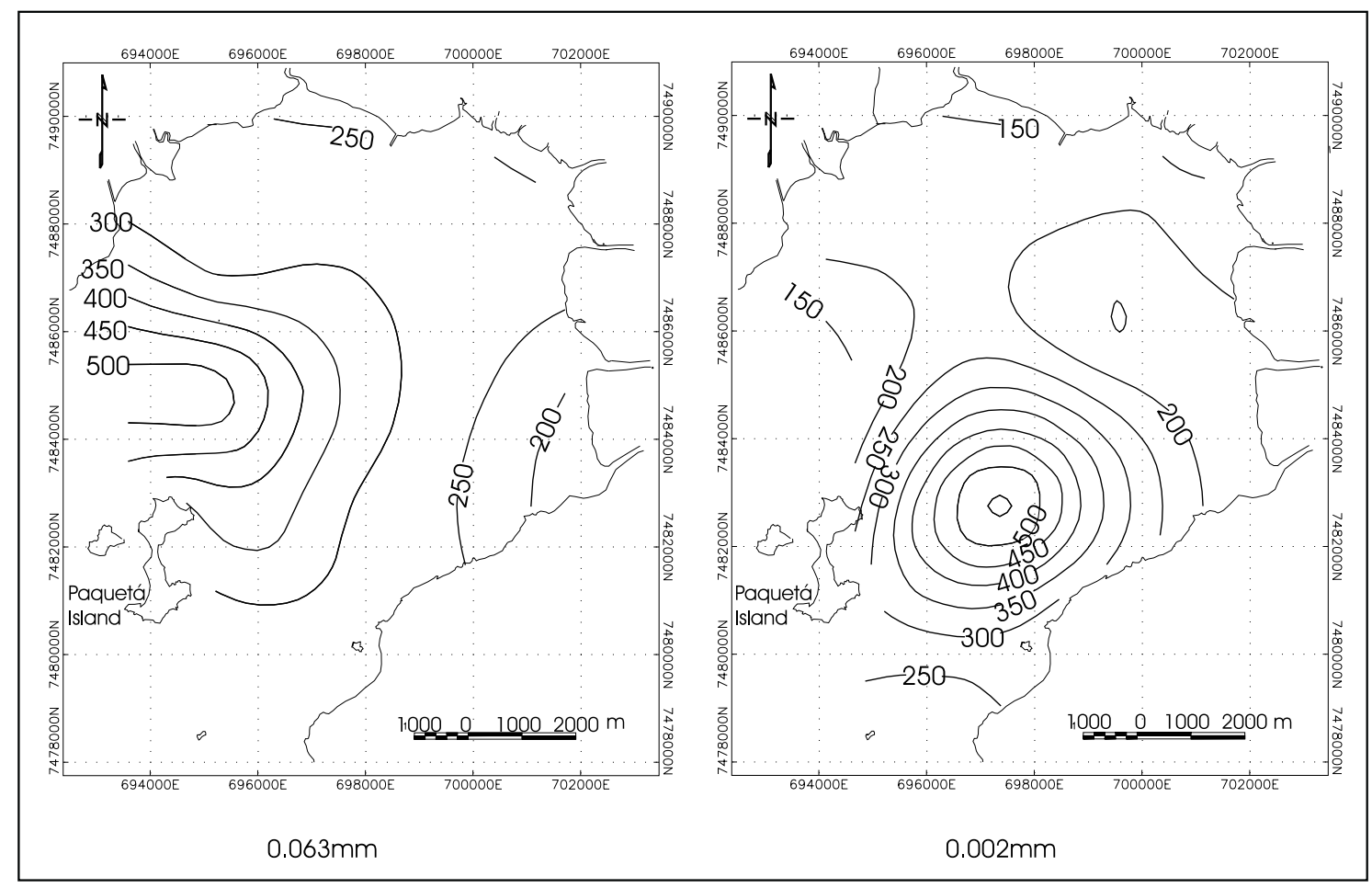

Fig. 8 - Zn distribution in bottom sediments of northeastern Guanabara Bay (contour lines are in ppm).

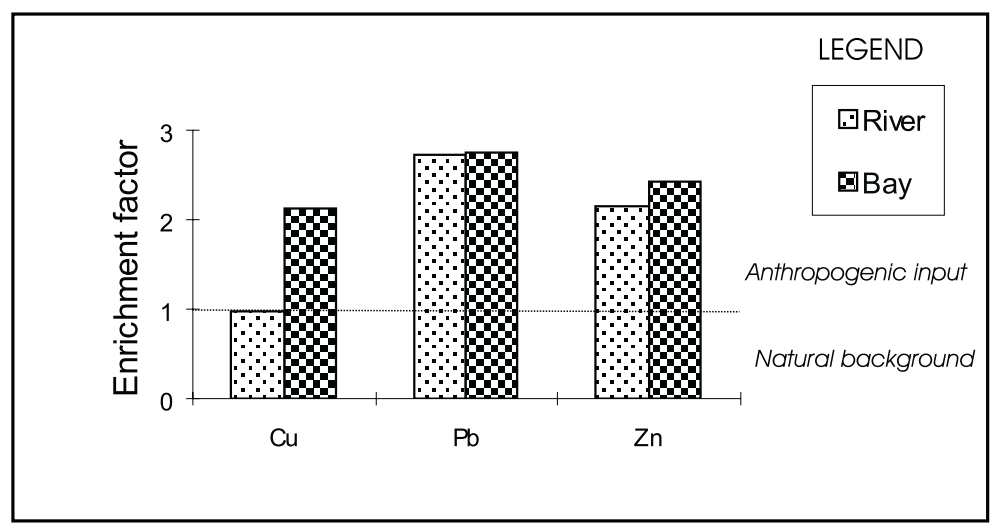

Fig. 9 - Comparison of average enrichment factors of fluvial and Guanabara Bay sediments.

vertidos em interestratificados e depositados no fundo da baía.

As análises geoquímicas dos metais pesados no sedimento da baía detectaram níveis de $\mathrm{Zn}$ e $\mathrm{Cu}$ superiores aos níveis encontrados nos sedimentos fluviais. Os perfis de con- centração dos rios estudados exibem um decréscimo na concentração dos metais ao longo de seus cursos, ao contrário da baía que apresenta maiores variações. De modo geral, as regiões de foz dos rios destacam-se pelas concentrações mínimas dos metais, e as áreas anômalas de 


\section{TABLE II}

\section{Metal ratios with average shale in bottom} sediments.

\begin{tabular}{l|rrr}
\hline Station & $\mathrm{Cu}$ & $\mathrm{Pb}$ & $\mathrm{Zn}$ \\
\hline $\mathrm{M} 1$ & 1,60 & 3,11 & 2,07 \\
$\mathrm{M} 2$ & 0,84 & 2,66 & 1,16 \\
$\mathrm{M} 3$ & 1,46 & 4,60 & 2,08 \\
$\mathrm{M} 4$ & 1,00 & 2,65 & 4,84 \\
$\mathrm{M} 5$ & 0,96 & 2,34 & 1,59 \\
$\mathrm{C} 1$ & 0,95 & 3,32 & 2,30 \\
$\mathrm{C} 2$ & 0,63 & 1,95 & 1,83 \\
$\mathrm{C} 3$ & 0,74 & 2,23 & 1,64 \\
$\mathrm{~B} 1$ & 1,61 & 4,05 & 3,99 \\
$\mathrm{~B} 2$ & 3,18 & 3,25 & 2,65 \\
$\mathrm{~B} 3$ & 2,97 & 2,04 & 2,19 \\
$\mathrm{~B} 4$ & 1,90 & 2,41 & 2,34 \\
$\mathrm{~B} 5$ & 7,11 & 3,72 & 5,67 \\
$\mathrm{~B} 6$ & 2,06 & 1,93 & 1,95 \\
$\mathrm{~B} 7$ & 1,59 & 2,97 & 2,00 \\
$\mathrm{~B} 8$ & 1,72 & 2,90 & 2,03 \\
$\mathrm{~B} 9$ & 0,67 & 3,02 & 1,39 \\
$\mathrm{~B} 10$ & 0,44 & 1,32 & 1,08 \\
$\mathrm{~B} 11$ & 0,49 & 3,29 & 2,25 \\
\hline
\end{tabular}

concentrações máximas situam-se ao Norte e a Leste da Ilha de Paquetá.

$\mathrm{O} \mathrm{Cu}$ tende a se concentrar na fração argila podendo estar associado aos argilominerais micáceos do alto curso. Entretanto, no baixo curso, outros componentes do sedimento podem controlar a retenção do $\mathrm{Cu}$ em função das bruscas mudanças das condições físico-químicas no ambiente estuarino. O Zn apresenta um comportamento instável ao longo dos rios e tende a se concentrar na Baía de Guanabara. Foram detectadas pequenas variações entre as concentrações de $\mathrm{Pb}$ dos sedimentos fluviais e da Baía de Guanabara. Este elemento tende a se concentrar mais na fração $<63 \mu$ m e não se associa a nenhum grupo de argilominerais.

Apesar dos fatores de enriquecimento dos metais pesados serem mais elevados na baía do que os fatores encontrados nos rios, os índices de acumulação de $\mathrm{Cu}, \mathrm{Pb}$ e $\mathrm{Zn}$ ainda classificam a área de estudo como não poluída tanto os rios como o setor NE da baía. Este estudo não indica estes rios como as principais fontes poluidoras de metais pesados na Baía de Guanabara.

Palavras-chave: metal pesado, argilomineral, sedimento, Baía de Guanabara .

\section{REFERENCES}

Alves DB. 1987. Desenvolvimento da metodologia de preparação de amostras para análise difratométrica de argilominerais no Centro de Pesquisas da PETROBRÁS. Boletim de Geociências da PETROBRÁS 1(2): 157-175.

Amador ES. 1992. Sedimentos de Fundo da Baía de Guanabara - Uma Síntese. In: III Congresso da Associação Brasileira de Estudos do Quaternário. Belo Horizonte, ABEQUA, 1992, p. 199-225.

Baptista Neto JA. 1996. Sedimentological Evidence for Human Impact on a Nearshore Sedimentary Environment: Jurujuba Sound, Rio de Janeiro State, Brazil. Ph.D dissertation, Belfast: Queen's University of Belfast, p. 351.

Chester R. 1990. Marine Geochemistry. London: Unwin Hyman Ltd, p. 698.

Chester R. \& Aston SR. 1976. Chemical Oceanography. New York: Academic Press, p. 304-320.

FARIA MM. 1997. Caracterização mineralógica e geoquímica dos sedimentos da porção NE da Baía de Guanabara e das suas áreas-fontes adjacentes. Tese de Mestrado, Niterói, Universidade Federal Fluminense, p. 147.

Faria MM, Sanchez BA, Smith B \& McAlister JJ. 1995. Níveis de Poluição por Metais Pesados em Sedimentos Superficiais da Porção Nordeste da Baía de Guanabara. Cd rom, $V$ Congresso Brasileiro de Geoquímica, Niterói, SBGq.

FörSTNER U \& WitTMAN G. 1981. Metal pollution in the aquatic environment. 2nd ed. Berlin: Springer Verlag, p. 484

Haekel W, Schroeder F, Felsen V, Rebelo A de Luca, Moreira I \& Santelli R. 1985. $C d, P b$, $\mathrm{Cu}, \mathrm{Cr}$ e $\mathrm{Hg}$ in Waters and Sediments of The Guanabara Bay Estuary. GKKS - Forschungszentrum Geesthacht GmbH - 85/E/21, p.18. 
IrION G \& Zöllmer V. 1990. Pathways of fine-grained clastic sediments - Examples from Amazon, the Weser Estuary, and the North Sea. In: Sediments and environmental geochemistry (Selected Aspects and Case Histories). Berlin: Springer-Verlag, p. 351366.

JACKSON ML. 1975. Soil chemical analysis, advanced course. 2.ed. Madison: published by author.

JICA (JAPAn International CoOperation Agency) 1994. The Study on Recuperation of The Guanabara Bay Ecosystem. Tokyo: Kokusay, Kogyo Co. Ltd., p. 73.

Malle KG. 1990. The pollution of the River Rhine with heavy metals. In: Sediments and environmental geochemistry (selected aspects and case histories). Berlin: Springer Verlag, p. 279-290.
Müller G. 1979. Schwermetalle in den Sedimenten des Rheins - Veränderungen seit, 1971. Umschau 79(24): 778-783.

Nimer E. 1989. Climatologia do Brasil. Rio de Janeiro: Instituto Brasileiro de Geografia e Estatística (IBGE).

PANDARINATH K \& Narayana AC. 1992. Clay Minerals and Trace Metal Association in the Gangoli Estuarine Sediments, West Coast of India. Estuarine, Coastal and Shelf Science 35: 363-370.

Rybicka EH, Calmano W \& Breeger A. 1995. Heavy metals sorption/desorption on competing clay minerals; an experimental study. Applied Clay Science 9: 369-381.

WiJayananda NP \& Cronan DS. 1994. The geochemistry and mineralogy of marine sediments from the eastern Indian Ocean. Marine Geology 117: 275285. 